\title{
Why smart water journal?
}

\author{
Philippe Gourbesville
}

Correspondence:

Philippe.GOURBESVILLE@unice.fr Polytech Nice Sophia, Nice Sophia Antipolis University, Nice, France

\section{Why smart water journal?}

Future water shortages require immediate action on development of resources, reduction of demand and higher efficiency in treatment and transmission. Future flood risk management requires immediate action in risk assessment, defence and alleviation systems, forecasting and warning systems and institutional and governance measures. Technology has been revolutionized over recent years and now, matured with mass production allowing wider uptake of methods and devices. After the development phase, technology is now entering an application and implementation phase that is targeting several fields including environment.

At the worldwide scale, Information and Communication Technologies (ICT) have been identified as a key factor for sustainable growth both where efficiency has to be achieved and where alternative to classical engineered solutions could be developed and implemented. In such context, ICT refer to technologies that provide access to information through telecommunications. It is similar to Information Technology (IT), but focuses primarily on communication technologies. This includes the Internet, wireless networks, cell phones, and other communication mediums that are today massively used in modern societies and reshaping deeply current business processes. A low level of maturity concerning standardization of ICT solutions and business processes characterizes the current situation in the water domain. The massive and rapid spread of communicating devices and their application to the industrial sectors is not really coordinated. The implementation of solutions is only driven by opportunities and partial visions that are related most of time to local conditions, demands and resources. The gradual rationalisation of ICT solutions for several domains like energy and water will request a formalization effort in order to identify how solutions may help to improve the water cycle management and provide real added value.

The water cycle can be addressed through three domains that are associated to specific activities and business processes:

- Protection of natural environment and ecosystems;

- Natural hazards mitigation and disaster prevention;

- Water uses.

The first domain considers all actions needed to assess and advice on the environmental impacts of development proposals and projects related to specific water uses. Results are used by regulatory services. The domain covers also all conservation actions of water related ecosystems.

(c) 2016 Gourbesville. Open Access This article is distributed under the terms of the Creative Commons Attribution 4.0 International License (http://creativecommons.org/licenses/by/4.0/), which permits unrestricted use, distribution, and reproduction in any medium, provided you give appropriate credit to the original author(s) and the source, provide a link to the Creative Commons license, and indicate if changes were made. 
The second domain is focused on water related natural hazards mitigation actions. Floods, droughts, water-borne and vector disease outbreaks, famines, landslide and avalanche events are the processes covered by this domain. Every year, disasters related to meteorological, hydrological and climate hazards cause significant loss of life, and set back economic and social development by years.

The last domain covers the added influence of human activity on the water cycle. Generally, the water uses refer to use of water by agriculture, industry, energy production and households, including in-stream uses such as fishing, recreation, transportation and waste disposal. All of those uses are directly linked to specific activities and processes that are potential targets for deployment of ICT solutions. According to the defined water domains, the water uses represent the largest field where ICT solutions can be developed and implemented. In the coming years, new approaches for the water cycle management will appear with the solutions deployment and their gradual integration within a global Information System (IS) offering interoperability and avoiding redundancy. The development of this approach will request a close collaboration among professionals from various communities: water and IT domains have to work closely for ensuring a consistent vision. For the time being, very few opportunities are offered to the both communities to exchange and to share. The Smart Water journal has the ambition to create a common space where visions, ideas, strategies, scientific results, innovations, technical experimentation results, standards from water and IT domains will be shared and discussed.

The Smart Water Journal is also an initiative of @qua - Smart ICT for Water. The motivation of the @qua entity (www.a-qua.org) which gathers major actors from water and ICT domains, is to ensure the interface with the different actors of the water domain and to elaborate a consistent vision for the future of ICT solutions within the water domain. This activity is essential in order to ensure a productive $R \& D / I T$ implementation focused on high benefit "niches" and to develop agile environments (interoperability) able to deal with the massive flow of data (Big Data) and constant technological innovation (M2M). The Smart Water Journal has the vocation to be the platform and the forum where visions can be shared. The journal scope covers emerging domains which overlaps the ICT and the water domain. Obviously the target audience includes researchers, professionals and stakeholders from the water and IT sectors, in particular practitioners from the industrial sector in order to promote standards, guidelines and good practices. The Smart Water Journal is published as an open publication in order to ensure a quick access to the articles and an efficient spreading within the professional communities. A growing numbers of international events are dedicated to the Smart Water concepts and it is essential to offer a specific space where ideas and results can be concentrated and referenced.

The Editorial board that gathers great experts and professionals who have accepted the challenge of the new journal, will be there to receive your contributions, suggestions, comments, advices in order to ensure the journal quality and to be sure that the publication serves the scientific and professional communities. With my colleagues of the board, I hope to hear from you soon either through submissions or ideas you might wish to share.

Dr. Philippe Gourbesville

Editor-in-Chief, SWJ 